\title{
BRS Violeta (BRS Rúbea $\times$ IAC 1398-21) grape juice powder produced by foam mat drying. Part I: Effect of drying temperature on phenolic compounds and antioxidant activity
}

\author{
Iasnaia Maria de Carvalho Tavares ${ }^{\mathrm{a}}$, Maurício Bonatto Machado de Castilhos ${ }^{\mathrm{b}}$, \\ Maria Aparecida Mauro ${ }^{a}$, Afonso Mota Ramos ${ }^{c}$, Reginaldo Teodoro de Souza ${ }^{\text {d, }}$ \\ Sergio Gómez-Alonso ${ }^{\mathrm{e}}$, Eleni Gomes ${ }^{\mathrm{a}}$, Roberto Da-Silva ${ }^{\mathrm{a}}$, Isidro Hermosín-Gutiérrez ${ }^{\mathrm{e}}$, \\ Ellen Silva Lago-Vanzela ${ }^{\text {a,* }}$

\footnotetext{
a São Paulo State University (UNESP), Institute of Biosciences, Humanities and Exact Sciences (Ibilce), Cristovão Colombo, 2265, Jardim Nazareth, 15054-000, Campus São, José do Rio Preto, São Paulo, Brazil

${ }^{\mathrm{b}}$ University of Minas Gerais State (UEMG), Frutal Unit, Avda. Professor Mário Palmerio, 1001, Universitário, 38200-000, Frutal, Minas Gerais, Brazil

${ }^{\mathrm{c}}$ University of Vicosa (UFV), Avenida Peter Henry Rolfs, $s / n$, Campus Universitário, 36570-000 Viçosa, Minas Gerais, Brazil

${ }^{\mathrm{d}}$ Brazilian Agricultural Research Corporation Grape and Wine (EMBRAPA), Jales, São Paulo, Brazil

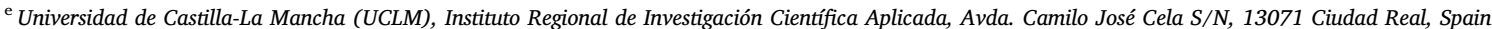

\section{A R T I C L E I N F O}

Chemical compounds studied in this article: Delphinidin 3-glucoside (PubChem CID: 443650)

Delphinidin 3,5-diglucoside (PubChem CID: 10100906)

Petunidin 3,5-diglucoside (PubChem CID 10151874)

Malvidin 3,5-diglucoside (PubChem CID: 44256978)

Myricetin (PubChem CID:5281672)

Myricetin 3-glucoside (PubChem CID:

44259426)

Quercetin 3-glucoside (PubChem CID:

44259229)

2-S-glutathionyl-trans-caftaric acid (PubChem

CID: 71308212)

trans-caftaric acid (PubChem CID: 13887348)

trans-fertaric acid (PubChem CID: 72551457)

Keywords:

BRS Violeta grape

Juice

\begin{abstract}
A B S T R A C T
The BRS Violeta grape presents pulp and skin with high content of phenolic compounds (PCs) and intense purplish color. It was used as raw material for the production of juice and dehydrated products using foam mat drying at 60,70 and $80^{\circ} \mathrm{C}$ and freeze drying (control). HLPC-DAD-ESI-MS ${ }^{n}$ allowed the evaluation of the quantitative and qualitative changes of the main PCs (anthocyanins, flavonols and hydroxycinnamic acid derivatives (HCAD)) present in the grapes during the processing. The use of the steam extraction method to obtain grape juice allowed a greater extraction of flavonols and, mainly derivatives of hydroxycinnamic acids, when compared with anthocyanins. Drying at $70{ }^{\circ} \mathrm{C}$ was the most suitable for the preservation of the PCs and, at the same time, for the reduction of the processing time. The powdered products presented considerable concentrations of total PCs (3-5 mg/g) and antioxidant activity (32-79 (DPPH) or 17-27 (FRAP) mg/g).
\end{abstract}

Abbreviations: dp, delphinidin; cy, cyanidin; pt, petunidin; pn, peonidin; mv, malvidin; M, myricetin; Q, quercetin; K, kaempferol; L, larycitrin; I, isorhamnetin; S,

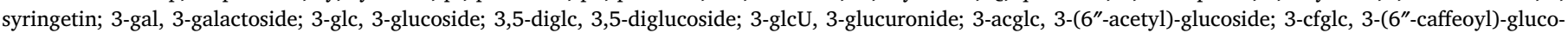

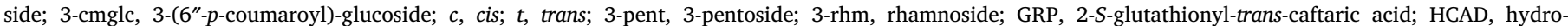

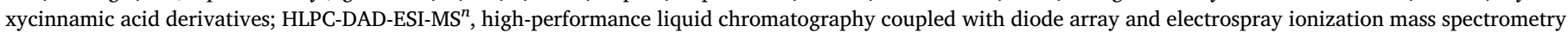

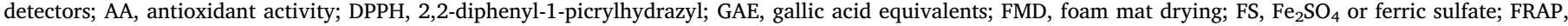

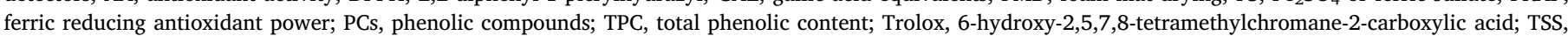
total soluble solids; TA, titratable acidity; ANOVA, analysis of variance; AOAC, association of official analytical chemists

* Corresponding author.

E-mail addresses: iasnaiamct@gmail.com (I. Maria de Carvalho Tavares), mauricio.castilhos@uemg.br (M. Bonatto Machado de Castilhos), maria.mauro@unesp.br (M. Aparecida Mauro), amotaramos@gmail.com (A. Mota Ramos), reginaldo.souza@embrapa.br (R. Teodoro de Souza), sergio.gomez@uclm.es (S. Gómez-Alonso), eleni.gomes@unesp.br (E. Gomes), roberto.silva@unesp.br (R. Da-Silva), isidro.hermosin@uclm.es (I. Hermosín-Gutiérrez), ellen.sl.vanzela@unesp.br (E. Silva Lago-Vanzela). 


\section{Introduction}

Fruit and vegetable juices and extracts have been widely used for the elaboration of colored dehydrated products rich in phenolic compounds, especially anthocyanins. These products have great potential for use as natural coloring in foods intended to confer attractive coloring, in addition to the appeal of health benefits (Cortez, Luna-Vital, Margulis, \& De Mejia, 2017; Lao \& Giusti, 2017; Moser et al., 2017; Wilkowska, Ambroziak, Czyzowska, \& Adamiec, 2016; Yamashita et al., 2017). However, it is known that each plant matrix is different, containing remarkably different quantities and kind of sugars and bioactive compounds. It is also known that the technology and temperature employed during elaboration can affect the sensory characteristics and the functional qualities of the dehydrated extracts. Spray drying and freeze-drying have been the most widely used methods for obtaining coloring in powder form due to the satisfactory preservation of thermolabile compounds, such as anthocyanins present in the fruits and vegetables (Cortez et al., 2017; Wilkowska et al., 2016). However, these dehydration techniques are more expensive and require skilled labor compared to other simpler and cheaper ones, such as foam mat drying (FMD). By this drying technique, a liquid product is converted into a stable foam by the addition of foaming, stabilizers and/or anti-moisture agents, followed by air drying, at relatively low temperatures and for short times in comparison to conventional drying, to form a thin porous layer which is crumbled to give a powder (Tavares et al., 2017).

The inclusion of additives (carbohydrates, proteins and gums) to obtain the foams may cause a dilution effect on the final products but this effect can be offset by the benefits that they can bring to the process, such as its complexation with pigments from the raw material (Lao \& Giusti, 2017) and an increase in its shelf-life (Duangmal, Saicheua, \& Sueeprasan, 2008).

Different raw materials have already been dehydrated using the FMD technique (Ekpong, Phomkong, \& Onsaard, 2016; Guimarães, Figueirêdo, \& Queiroz, 2017; Sangamithra, Venkatachalam, John, \& Kuppuswamy, 2015; Tavares et al., 2017). However, there is little information about the effect of the drying temperatures used on the profile of the anthocyanins and other phenolic compounds of interest present in the vegetable matrices to dehydrate by FMD. There are also few reports exploring the potential of these powdered products for use as a natural coloring rich in anthocyanins (Abbasi \& Azizpour, 2016; Tavares et al., 2017).

The BRS Violeta grape (a hybrid obtained from 'BRS Rúbea' $\times$ 'IAC

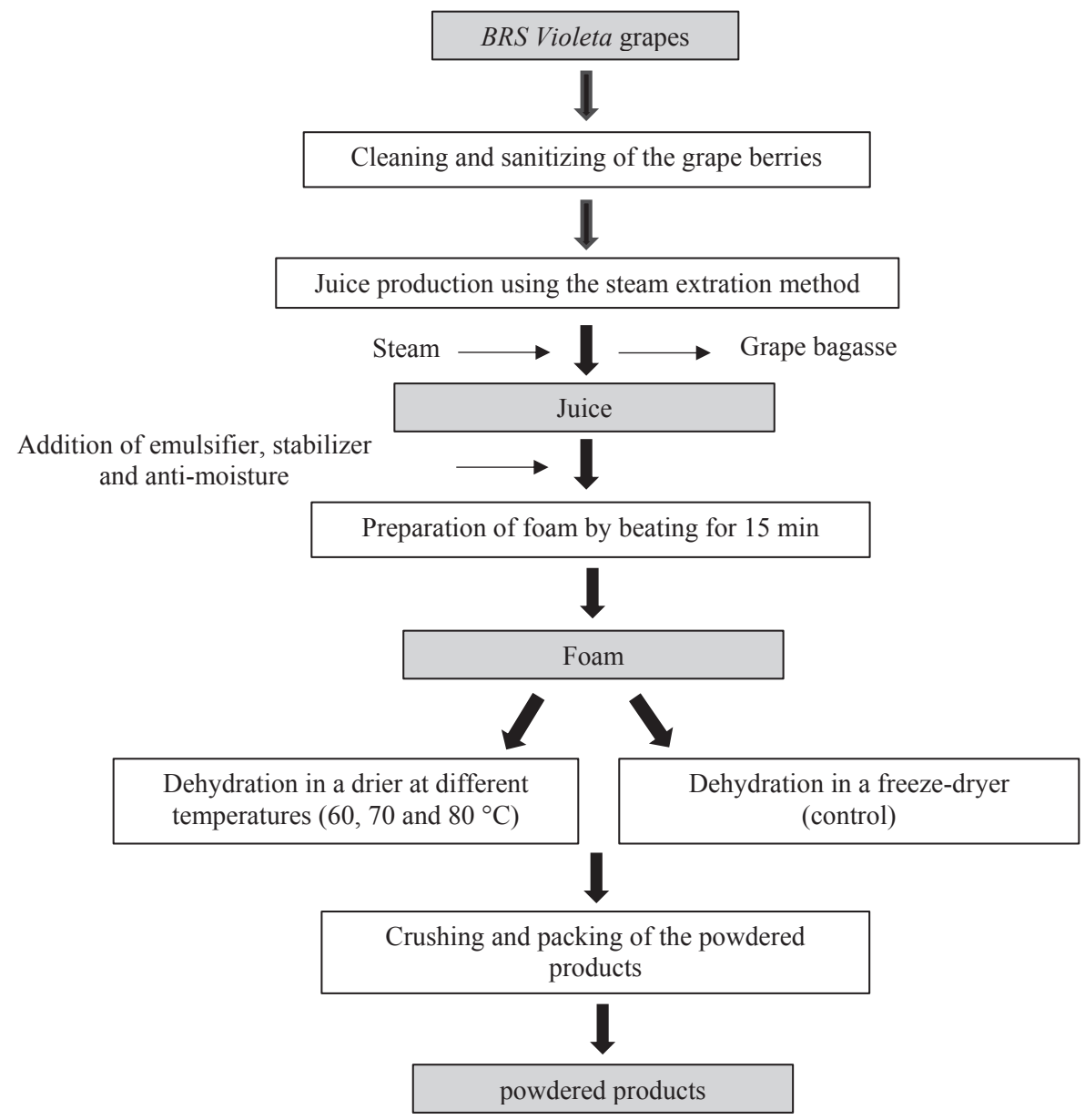

Fig. 1. Flow diagram summarizing the stages of preparation of the powdered products. 
1398-21'), developed by the Brazilian Agricultural Research Corporation (Embrapa) has interesting characteristics that make it a possible raw material for research into its use for the elaboration of a dehydrated product using the FMD method. This cultivar presents pulp and, mainly, skins with high content of phenolic compounds (Rebello et al., 2013). In the literature, this grape has been exploited for the production of juices (Lima et al., 2014), wines (Lago-Vanzela et al., 2014; Castilhos et al., 2016) and dehydrated products in powdered form using a spray drier (Moser et al., 2017).

The objective of this study was to dehydrate BRS Violeta grape juice using the FMD method testing different temperatures $\left(60,70\right.$ and $\left.80^{\circ} \mathrm{C}\right)$ and comparing them to the freeze-drying dehydration process. Quantitative and qualitative changes during dehydration in phenolic compounds (anthocyanins, flavonols and hydroxycinnamic acid derivatives (HCAD)) were determined using HPLC-DAD-ESI-MS ${ }^{n}$. In addition, changes in the total phenolic compounds (TPC) content and antioxidant activity (AA) in both the juice and the powdered products were also assessed.

\section{Materials and methods}

\subsection{Materials}

The chemical standards malvidin (mv) 3-glucoside, mv 3,5-diglucoside, peonidin (pn) 3,5-diglucoside, quercetin (Q) 3-glucuronide, $p$ coumaric acid and trans-caftaric acid were from Phytolab (Vestenbergsgreuth, Germany). The other chemical standards - cyanidin (cy) 3-glucoside, cy 3,5-diglucoside, Q, kaempferol (K), isorhamnetin (I), myricetin (M), syringetin (S); the 3-glucosides of Q, K, I, and S; 3-galactosides of $\mathrm{Q}, \mathrm{K}, \mathrm{I}$ - were from Extrasynthese (Genay, France). The chemical standard caffeic acid was from Sigma Aldrich (Tres Cantos, Spain). The chemical standard laricitrin 3-glucoside has been previously isolated from Petit Verdot grape skins (Castillo-Muñoz et al., 2009), because it is a commercially unavailable standard. All solvents and chemical standards were of chromatographic (>99\%) and analytical (> 95\%) grades, respectively.

The additives used to aid in the formation and stability of the foam, Emustab $^{\circledR}$ (Selecta, Jaguará do Sul, Brazil), Super Liga Neutra ${ }^{\circledR}$ (Selecta, Jaguará, Brazil) and maltodextrin 10 DE (Ingredion, Mogi Guaçu, Brazil), were acquired from local trade.

BRS Violeta grapes (vintage of 2013), healthy and at a commercial stage of maturation, were donated by the Embrapa, Jales, Brazil, located at $20^{\circ} 15^{\prime} 08^{\prime \prime} \mathrm{S}$ and $50^{\circ} 33^{\prime} 29^{\prime \prime} \mathrm{W}$, and $500 \mathrm{~m}$ above sea level (refer to WGS84 datum), according to World Geodetic System. 1984 (1984). The BRS Violeta grape presented, on average, $66.84 \pm 1.26 \%$ of the pulp, $27.39 \pm 0.71 \%$ of the skin and, $5.78 \pm 0.65 \%$ of the seed. The characteristics of the grape were determined according to the AOAC (2005), in triplicate, the values being: moisture content, $76.33 \pm 1.17 \% ; \mathrm{pH}, 3.49 \pm 0.05$; titratable acidity content (TAC), $1.49 \pm 0.10 \mathrm{~g}$ of tartaric acid/ $100 \mathrm{~g}$ of grape; soluble solids (SS), $19.98 \pm 0.99$ Brix; and SS/TAC ratio of $12.58 \pm 0.60$. The berry size is $15 \times 14 \mathrm{~mm}$ and the berry weight, $0,63 \pm 0.05 \mathrm{~g}$.

\subsection{BRS Violeta grape juice powders}

The steps for obtaining the powdered products are shown in Fig. 1. First, $2 \mathrm{~kg}$ of BRS Violeta grapes were used to obtain the juice, in triplicate, by means of a stainless steel steamer pan (Sugar Sucos, Bento Goncalves, Brazil). This pan is composed of a lower water tank, which is heated to generate steam, followed by an intermediate container which contains a tapered opening in the center for the passage of steam and a lateral opening for the outflow of juice and a perforated upper container where the grapes are placed. Extraction took place by means of saturated steam for $2.5 \mathrm{~h}$ at $85^{\circ} \mathrm{C}$ (Bresolin, Gularte, \& Manfroi, 2013). To maintain microbiological stability, the bottled juices were cooled and stored $\left( \pm 10^{\circ} \mathrm{C}\right)$ until use. The percentage of juice yield was
$88.60 \pm 1.88 \%(\mathrm{w} / \mathrm{w})$, corresponding to the ratio between the weight of the juice extracted and the initial mass of the grapes. The physicochemical characteristics of the juice were determined according to AOAC (2005), in triplicate, the values being: moisture content, $85.11 \pm 2.33 \% ; \mathrm{pH}, 3.54 \pm 0.04$; TAC, $1.14 \pm 0.12 \mathrm{~g}$ of tartaric acid/100 mL of juice; SS, $14.37 \pm 0.70{ }^{\circ} \mathrm{Brix}$; and SS/TAC ratio of $13.14 \pm 0.85$.

Dehydration of the grape juice using the FMD technique followed a method similar to that described by Tavares et al. (2017). In the present study, the foams used (200 g each) contained: juice, emulsifier (Emustab ${ }^{\circledast}$ ), stabilizer (Super Liga Neutra ${ }^{\circledR}$ ) and anti-moisture (10 DE Maltodextrin), in the proportions of 71.5:12.5:1.0:15.0, w/w, respectively. In order to obtain the foams, these ingredients were subjected to beating with the aid of domestic mixer (Philips Walita ${ }^{\circledR}$, São Paulo, Brazil), at full speed for $15 \mathrm{~min}$. The foams were placed in stainless steel trays ( $150 \mathrm{~mm}$ radius, $5 \mathrm{~mm}$ height), dried in a hot-air dryer $(0.42 \mathrm{~m} / \mathrm{s}$ ) at 60,70 , and $80^{\circ} \mathrm{C}$ until equilibrium moistures were achieved, and immediately vacuum packed, anaerobically and in the dark. To obtain powdered products (control), foams were frozen at $-80^{\circ} \mathrm{C}$ and dried in a freeze-dryer FR-Dying Digital Unit (Thermo Fisher Scientific, Waltham, USA) for $24 \mathrm{~h}$. These samples were used as control. All dried foams were removed from the stainless steel spatula. Pieces were crushed with the aid of a pestle and mortar to obtaining the powdered products and were immediately packed in metalized packages without light and oxygen.

The physicochemical characteristics (moisture content, $\mathrm{pH}, \mathrm{TAC}$ ) of the powdered products (from both FMD and freeze-drying) were determined according to AOAC (2005) in triplicate, the values being: moisture content, $3.99 \pm 0.39 \%$ and $6.40 \pm 0.23 \%$; $\mathrm{pH}, 3.80 \pm 0.11$ and $3.83 \pm 0.04$; TAC, $2.51 \pm 0.41$ and $2.34 \pm 0.14$ of $g$ tartaric acid/100 $\mathrm{g}$ of powder, respectively.

\subsection{Determination of PCs by HPLC-DAD-ESI-MS ${ }^{n}$}

For the quantitative and qualitative determinations of anthocyanins, flavonols, and HCAD profiles in the grape and derived products were prepared different extracts. For the grape, the edible parts (skin and flesh) were used for the extraction of phenolic compounds using method described by Lago-Vanzela, Da-Silva, Gomes, García-Romero, and Hermosín-Gutiérrez (2011). The juice samples as well as the extracts obtained from the parts of the grapes were lyophilized and at the moment of analyses were re-dissolved in $50 \mathrm{~mL}$ of $\mathrm{HCl} 0.1 \mathrm{~N}$. For the acquisition of dehydrated products extracts, the method used was the described by Tavares et al. (2017). All procedures were performed in triplicate.

For the PCs (anthocyanins, flavonols and HCAD), analysis by HPLCDAD-ESI- MS ${ }^{n}$ of the grape (edible parts - skin and flesh), juice and dehydrated products using freeze drying and FMD $\left(60,70\right.$ and $\left.80^{\circ} \mathrm{C}\right)$ additional steps were required. In the case of anthocyanins analyses, aliquots of the prepared samples were diluted with $\operatorname{HCl} 0.1 N(1: 10,1: 9$ and $1: 0 \mathrm{v} / \mathrm{v}$ for the grape, juice, and powder extracts, respectively), and directly injected onto the chromatographic column $(10 \mu \mathrm{L}$ for the grape extracts, and $20 \mu \mathrm{L}$ for the juice and powder extracts). For the analysis of flavonols and HCAD, aliquots of grape $(3 \mathrm{~mL})$, juice $(2 \mathrm{~mL})$, and powder $(5 \mathrm{~mL})$ extracts were subjected to solid-phase extraction in Bond Elut Plexa PCX cartridges $\left(6 \mathrm{~cm}^{3}, 500 \mathrm{mg}\right.$ of adsorbent, Agilent, Santa Clara, US) to remove anthocyanins (Castillo-Muñoz et al., 2009). These anthocyanin-free extracts were filtered $(0.20-\mu \mathrm{m}$ polyester membrane, Chromafil PET 20/25) and injected directly (20 $\mu \mathrm{L})$ into the same chromatographic system as that used for the anthocyanin analysis.

Phenolic extracts of the grape, juice, and powdered product samples were analyzed according to a previously described method (Rebello et al., 2013). For PCs identification, an ion trap ESI-MS/MS analyzer was used in positive (for anthocyanins) and negative (for flavonols and HCAD) ionization modes, as previously described (Rebello et al., 2013). 


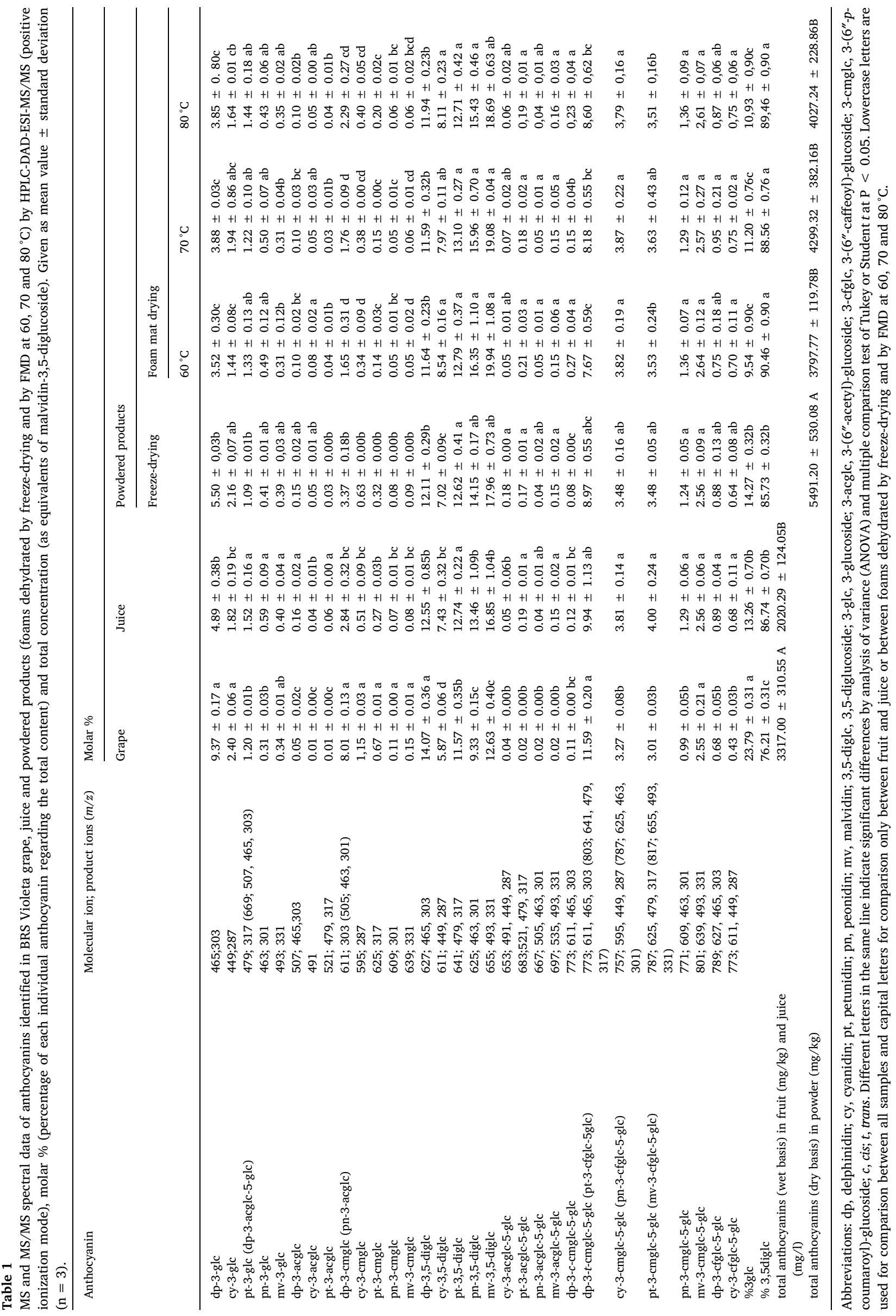


The ionization and fragmentation parameters were optimized by a direct infusion of the appropriate standard solutions (malvidin 3,5-diglucoside, mv-3,5-diglc, in positive ionization mode; quercetin 3-glucoside, Q 3-glc and caftaric acid in negative ionization mode). The identification of PCs was mainly based on spectroscopic data (UV-Vis and MS/MS) for standards or data previously reported (Castillo-Muñoz et al., 2009; Lago-Vanzela et al., 2011; Rebello et al., 2013; Tavares et al., 2016, 2017).

For quantitative determination of PCs, were extracted DAD chromatograms at $520 \mathrm{~nm}$ (for anthocyanins), $360 \mathrm{~nm}$ (for flavonols) and $320 \mathrm{~nm}$ (for HCAD) using external standard calibration curves. The calibration standard solutions were prepared by dilution of an appropriate aliquot of the stock solutions of mv-3,5-diglc (from 1.5 to $125.0 \mathrm{mg} / \mathrm{L}$ ) for anthocyanins, Q-3-glc (from 5.0 to $100.0 \mathrm{mg} / \mathrm{L}$ ) for flavonols and caftaric acid (from 0.0 to $100.0 \mathrm{mg} / \mathrm{L}$ ) for HCDA. The total concentrations of anthocyanins, of flavonols and of HCDA were expressed as mg of mv-3,5-diglc equivalents, as mg of Q-3-glc equivalents and $\mathrm{mg}$ of caftaric acid, respectively, per L or $\mathrm{kg}$ of sample. To calculate the $\%$ age gain or loss of this compounds after processing the grape into juice were used the average juice yield and the amount to each compound in the grape and juice.

\subsection{Determination of TPC content and $A A$}

The method described by Ough and Amerine (1988) and BrandWilliams, Cuvelier, and Berset (1995) were used for determination of TPC. For the determination of AA were used two methods, the 2,2-diphenyl-1-picrylhydrazyl (DPPH) and the ferric reducing antioxidant power (FRAP) method, described for Brand-Williams et al. (1995) and Benzie and Strain (1996), respectively. For the prepare of the TPC and AA calibration curves were used gallic acid (GA) and 6-hydroxy2,5,7,8-tetramethylchromane-2-carboxylic acid (Trolox), respectively. To facilitate the comparisons of the results with data from literature, a calibration curve was also prepared using ferric sulfate $\left(\mathrm{Fe}_{2} \mathrm{SO}_{4}, \mathrm{FS}\right)$ for quantification of AA by FRAP. The results were expressed in $\mathrm{mg}$ of GA or Trolox or FS/g of grape or powdered product, or per $\mathrm{mL}$ of juice.

\subsection{Statistical analysis}

For data interpretation, the analysis of variance (ANOVA) was used and the means of the data were compared using the Tukey test or $t$ test with significance level was set at 0.05 . Statistical analyzes were performed using the statistical software Minitab 17 Statistical Software.

\section{Results and discussion}

Before producing the powdered products from BRS Violeta grape juice using FMD, several tests were carried out to determine the type and quantity of additives to be mixed with the juice. Although the use of Emustab ${ }^{\circledR}$ emulsifier and Super Liga Neutra ${ }^{\circledR}$ stabilizer have achieved excellent results in producing mango (Guimarães et al., 2017) and cajamanga (Spondias dulcis) powders (Breda, Justi, \& Sanjinez-Argandoña, 2013), in the current research, using only these two additives did not produce the desired powdered product. Fruit juices, such as grapes, have a high content of low molecular weight sugars (such as fructose and glucose). As a consequence, the powdered products with only these two additives were viscous and gummy in appearance, agreeing with the description of other authors (Saavedra-Leos, Alvarez-Salas, Esneider-Alcalá, Toxqui-Terán, \& Ruiz-Cabrera, 2012; Seerangurayar, Manickavasagan, Al-Ismaili, \& Al-Mulla, 2017).

The solution to this technological difficulty was found by adding maltodextrin along with the two other additives to the juice, as it is recognized as an efficient drying aid (Saavedra-Leos et al., 2012) for the production of dehydrated products by freeze-drying (Duangmal et al., 2008; Yamashita et al., 2017) and spray drying (Lao \& Giusti, 2017; Moser et al., 2017; Wilkowska et al., 2016) though it is still little used in
FMD (Abbasi \& Azizpour, 2016; Ekpong et al., 2016; Sangamithra et al., 2015; Tavares et al., 2017). The addition of maltodextrin resulted in a powdered product in the form of flakes, which was then triturated to obtain a more homogenous powder to perform the analyzes.

Once the foam formulation was defined, this foam was dehydrated at 60,70 , and $80^{\circ} \mathrm{C}$ until sample weights were constant (triplicates). These powdered products were obtained after $6.25 \pm 0.25$, $3.17 \pm 0.29$, and $2.67 \pm 0.24 \mathrm{~h}$, respectively. The drying time decreased with increasing temperature: when compared to the drying time of the foams at $60^{\circ} \mathrm{C}$, the mean time at $70{ }^{\circ} \mathrm{C}$ showed a reduction of approximately $39 \%$ while a reduction of approximately $52 \%$ was observed in the drying time at $80^{\circ} \mathrm{C}$. In a study by Bastos, Soares, Araújo, and Verruma-Bernardi (2005) on mango pulp dehydration using FMD at different temperatures, the authors used sorbitan monostearate (Tween 60 ) as emulsifier for foaming and observed a $37.5 \%$ reduction in process time when the drying air temperature increased from $70{ }^{\circ} \mathrm{C}$ to $85^{\circ} \mathrm{C}$. Similar reductions were also observed by other authors (Guimarães et al., 2017; Ekpong et al., 2016; Tavares et al., 2017). The reduction in the average drying time is important when considering an industrial scale process because the lower the drying time, the lower the energy expenditure and, consequently, the cost of production, reflecting positively on the final value of the product that will be passed on to the consumer. Moreover, longer drying times lead to longer exposure to high temperature and oxygen of the compounds of interest, such as phenolic compounds.

The quantitative and qualitative changes of grape PCs (anthocyanins, flavonols and HCAD), TPC and AA after processing to produce the juice and the powdered products are reported below.

\subsection{Anthocyanins}

Thirty-five anthocyanins were detected in all samples (fruit, juice and powdered products), present in the Table 1 , namely the non-acylated 3-glucosides (3-glc) of dp, cy, pt, pn and mv and their corresponding acetyl and $p$-coumaroyl derivatives, except for the acetyl derivative of $\mathrm{mv}$; and the 3,5-diglucosylated (3,5-diglc) compounds derived from dp, cy, pt, pn and $\mathrm{mv}$ in the non-acylated form and their corresponding acetyl, $p$-coumaroyl and caffeoyl derivatives. The delphinidin 3-(6"-p-coumaroyl)-glucoside-5-glucoside was found in both the cis and in trans forms. The anthocyanins with higher molar ratios in the grape and derived products (juice and powdered products) were the 3,5-diglc derivatives of the three B-ring tri-substituted anthocyanidins (dp, pt, and $\mathrm{mv}$ ), with $36-48 \%$ of the total anthocyanin content. Rebello et al. (2013) found a similar profile, with the exception of the minor acetyl derivatives of the 3-glc of $\mathrm{dp}$, cy, pt, and pn and the $p$ coumaroyl derivative of dp-3,5-diglc, which in this work was identified in two forms (cis and trans).

After processing the grape to obtain juice and subsequently processing the juice to obtain the powders by FMD at the different temperatures, there were significant reductions $(\mathrm{P}<0.05)$ in the molar ratios (sum) of 3-glc anthocyanins (24 to $13 \%$ and 13 to $9.5-11 \%$, respectively). Conversely, the molar ratios of 3,5-diglc anthocyanins increased, from 76 to $87 \%$ from the grape to the juice and from 87 to $88.5-90 \%$ from the juice to the powdered products. There was no significant difference between the 3-glc and 3,5-diglc molar proportions of the juice and the lyophilized product (control).

The reduction was notably higher for the delphinidin derivatives which has the largest molar ratio among the anthocyanins (3-glc and 3,5-diglc derivatives), with a consequent increase in the other three principals, the 3,5-diglc derivatives of pt, pn and mv. Barcia, Pertuzatti, Gómez-Alonso, Godoy, and Hermosín-Gutiérrez (2014) dried BRS Violeta grape winemaking by-products (skins and less) by different methods (oven drying at $50{ }^{\circ} \mathrm{C}$, spray-drying and freeze-drying). When comparing the profile of anthocyanins present in the skins dehydrated by freeze drying with those dried at $50^{\circ} \mathrm{C}$ they found the anthocyanins derived from 3-glc and 3,5-glc of delphinidin decreased the most. On 
the other hand, especially the mv- and pn-derived non-acylated 3,5diglc anthocyanins increased their molar rations. This is very likely because the 3,5-diglc anthocyanins derived from mv and pt, which are methoxylated tri-substituted anthocyanidins, and from pn, which is a methoxylated disubstituted anthocyanidin, seem to be more resistant to thermal and/or oxidative degradation than the 3,5-diglc anthocyanins derived from $\mathrm{dp}$ and cy, which are non-methoxylated tri- and disubstituted anthocyanins, respectively.

After the processing the fruit to obtain juice and, subsequently, the juice to obtain the powdered products, there were the same or increased molar proportions referring to the p-coumaroylated 3,5-diglc anthocyanins. In these anthocyanins, the $p$-coumaroyl group is present, which is involved in the formation of both inter- and intra-molecular co-pigmentation complexes, thus contributing to increased stability of the molecules. Similar results were reported by Lago-Vanzela et al. (2014) who evaluated the degradation kinetics of the BRS Violeta wine anthocyanins after storage at $15,25,35$ and $50{ }^{\circ} \mathrm{C}$. In that study, the authors reported that acylated anthocyanins, especially the $p$-coumaroylated ones, are more resistant to storage at higher temperatures when compared to non-acylated ones, and that the 3-glc anthocyanins were less stable than the respective 3,5-diglc derivatives. These results strongly support the idea that the anthocyanin structure affects its stability.

Regarding absolute concentration of anthocyanins, the BRS Violeta grape, used as raw material, presented a concentration of anthocyanins of approximately $3317 \mathrm{mg} / \mathrm{kg}$ of fresh grape as equivalents of mv-3,5diglc (Table 1), a lower value to that found by Rebello et al. (2013) ( $3950 \mathrm{mg} / \mathrm{kg}$ ) for the same cultivar. It is known, however, that vintage, harvest and climatic conditions and other extrinsic factors such as incidence of UV radiation and soil composition may influence the concentration of these and other grape phenolic compounds (Granato, Carrapeiro, Fogliano, \& Van Ruth, 2016).

Regarding the process of obtaining juice, the use of steam extraction was able to extract $54 \%$ of the total anthocyanins present in the grape (after conversion of the data using juice yield), which corresponds to a concentration of anthocyanins of $2020 \mathrm{mg}$ equivalent of mv-3,5-diglc/L of juice. This value is close to that found by Moser et al. (2017) in BRS Violeta grape juice $(1965 \mathrm{mg} / \mathrm{L})$ obtained by the same method of extraction. This way of producing juice is commonly used in smallholdings and on a semi-industrial scale. Extractor pans are available in different sizes and capacities, which can, if desired, be used in series, optimizing processing time and the amount of juice produced (Bresolin et al., 2013). The use of saturated steam to extract the juice has other advantages, besides being an easy and inexpensive process, because if the juice is packaged in the correct way, it does not require subsequent steps such as pasteurization and avoids turbidity by only extracting soluble compounds (Dutra, Lima, Barros, Mascarenhas \& Lafisca, 2014). Producing grape juice by steam extraction is a good alternative for the small producer, who can use their excess harvest to produce a higher value product, and so increase the family income (Rizzon, Manfroi, \& Meneguzzo, 1998). On the other hand, exposure of the grapes to saturated steam $(2.5 \mathrm{~h})$ and incorporation into the exogenous water product, inherent in the steam extraction process, might have contributed to the reduction of the content of anthocyanins. After destemming the BRS Violeta grape, crushing, enzymatically treating with pectinase and macerating at $60^{\circ} \mathrm{C}$ for $1 \mathrm{~h}$, Lima et al. (2014) obtained juice with an anthocyanin concentration far below that found in this study $(464 \mathrm{mg}$ of cyanidin 3-glucoside (cy-3-glc)/L of juice or $677 \mathrm{mg}$ equivalent of mv-3,5-diglc/L).

For the preparation of powdered products, some additives were added to the grape juice to produce stable foams that were dehydrated by freeze drying and drying at the three temperatures used in the study. The concentration of anthocyanins in the powdered products ranged from 3797 to $5491 \mathrm{mg}$ equivalent of mv-3,5-diglc/kg of powder (dry basis). Moser et al. (2017) produced BRS Violeta grape juice powders, with the addition of additives (maltodextrin and proteins), by spray

Table 2

Flavonols in BRS Violeta grape, juice and powdered products (foams dehydrated by freeze-drying and by FMD at 60,70 and $80{ }^{\circ} \mathrm{C}$ ) by HPLC-DAD-ESI-MS/MS (negative ionization mode). MS and MS/MS spectra data, molar \% (percentage of each individual flavonol regarding the total content), and total concentrations (as equivalents of quercetin-3-glucoside). Given as mean values \pm standard deviation $(\mathrm{n}=3)$.

\begin{tabular}{|c|c|c|c|c|c|c|c|}
\hline \multirow[t]{3}{*}{ Flavonol } & \multirow{3}{*}{$\begin{array}{l}\text { Molecular ion; product } \\
\text { ions }(\mathrm{m} / \mathrm{z})\end{array}$} & \multicolumn{6}{|l|}{ Molar \% } \\
\hline & & \multirow[t]{2}{*}{ Grape } & \multirow[t]{2}{*}{ Juice } & \multirow[t]{2}{*}{ Powdered products } & \multicolumn{3}{|l|}{ Foam mat drying } \\
\hline & & & & & $60^{\circ} \mathrm{C}$ & $70^{\circ} \mathrm{C}$ & $80^{\circ} \mathrm{C}$ \\
\hline M-3-glcU & $493 ; 317$ & $5.81 \pm 0.59 \mathrm{a}$ & $5.13 \pm 0.76 \mathrm{a}$ & $4.17 \pm 0.54 \mathrm{a}$ & $4.68 \pm 0.76 \mathrm{a}$ & $4.82 \pm 0.02 \mathrm{a}$ & $1.53 \pm 2.16 \mathrm{~b}$ \\
\hline M-3-glc & $479 ; 317$ & $66.30 \pm 3.16 \mathrm{a}$ & $49.73 \pm 6.27 b$ & $55.05 \pm 3.49 \mathrm{ab}$ & $43.61 \pm 11.06 b$ & $55.12 \pm 0.10 \mathrm{ab}$ & $17.51 \pm 14.41 c$ \\
\hline Q-3-glcU & 477; 301 & $6.74 \pm 0.95 b$ & $8.05 \pm 1.53 b$ & $12.09 \pm 1.59 \mathrm{a}$ & $8.56 \pm 2.66 \mathrm{ab}$ & $8.60 \pm 2.67 \mathrm{ab}$ & $5.52 \pm 1.02 b$ \\
\hline Q-3-glc & $463 ; 301$ & $8.88 \pm 0.17 \mathrm{ab}$ & $10.08 \pm 1.45 \mathrm{a}$ & $10.99 \pm 0.46 \mathrm{a}$ & $10.81 \pm 3.23 \mathrm{a}$ & $11.90 \pm 0.01 \mathrm{a}$ & $4.09 \pm 3.76 b$ \\
\hline L-3-glc & $493 ; 331$ & $3.51 \pm 0.53 \mathrm{a}$ & $3.59 \pm 0.30 \mathrm{a}$ & $3.90 \pm 0.51 \mathrm{a}$ & $3.83 \pm 0.94 \mathrm{a}$ & $4.29 \pm 0.09 \mathrm{a}$ & $3.73 \pm 0.56 \mathrm{a}$ \\
\hline I-3-glc & $477 ; 315$ & $0.61 \pm 0.06 \mathrm{ab}$ & $0.86 \pm 0.18 \mathrm{a}$ & $0.78 \pm 0.12 a b$ & $0.89 \pm 0.22 \mathrm{a}$ & $0.80 \pm 0.01 \mathrm{a}$ & $0.28 \pm 0.40 \mathrm{~b}$ \\
\hline S-3-glc & $507 ; 345$ & $3.00 \pm 0.12 b$ & $4.00 \pm 0.44 b c$ & $7.59 \pm 0.76 \mathrm{a}$ & $3.74 \pm 0.60 \mathrm{bc}$ & $3.93 \pm 0.07 b$ & $1.97 \pm 1.28 \mathrm{c}$ \\
\hline M free & $317 ; 317$ & $5.16 \pm 1.59 b$ & $13.78 \pm 5.61 b$ & $5.44 \pm 4.97 b$ & $17.95 \pm 14.79 b$ & $7.29 \pm 0.23 b$ & $47.77 \pm 16.94 \mathrm{a}$ \\
\hline Q free & $301 ; 301$ & ND & $3.44 \pm 1.23 \mathrm{~b}$ & ND & $4.31 \pm 3.22 \mathrm{ab}$ & $2.22 \pm 0.20 \mathrm{~b}$ & $11.32 \pm 2.59 \mathrm{a}$ \\
\hline $\mathrm{L}$ free & $331 ; 331$ & ND & $0.321 \pm 0.16 \mathrm{a}$ & ND & $0.34 \pm 0.49 \mathrm{a}$ & $0.18 \pm 0.26 \mathrm{a}$ & $3.04 \pm 3.08 \mathrm{a}$ \\
\hline I free & $315 ; 315$ & ND & $0.24 \pm 0.20 \mathrm{a}$ & ND & $0.28 \pm 0.39 \mathrm{a}$ & $0.31 \pm 0.08 \mathrm{a}$ & $0.63 \pm 0.03 \mathrm{a}$ \\
\hline$S$ free & $345 ; 345$ & ND & $0.79 \pm 0.26 b$ & ND & $1.00 \pm 0.67 \mathrm{ab}$ & $0.45 \pm 0.09 b$ & $2.61 \pm 0.94 \mathrm{a}$ \\
\hline M-type & & $77.27 \pm 1.70 \mathrm{a}$ & $68.65 \pm 3.85 b$ & $64.65 \pm 2.48 b$ & $66.24 \pm 2.98 b$ & $67.23 \pm 0.31 b$ & $66.81 \pm 0.37 b$ \\
\hline Q-type & & $15.62 \pm 1.11 b$ & $21.56 \pm 3.13 a b$ & $23.08 \pm 1.79 \mathrm{a}$ & $23.68 \pm 2.77 \mathrm{a}$ & $22.71 \pm 0.27 \mathrm{ab}$ & $20.93 \pm 2.18 \mathrm{ab}$ \\
\hline L-type & & $3.51 \pm 0.53 b$ & $3.90 \pm 0.22 b$ & $3.90 \pm 0.51 b$ & $4.18 \pm 0.45 b$ & $4.23 \pm 0.35 \mathrm{ab}$ & $6.77 \pm 2.52 \mathrm{a}$ \\
\hline I-type & & $0.61 \pm 0.06 \mathrm{~b}$ & $1.10 \pm 0.21 \mathrm{ab}$ & $0.78 \pm 0.78 \mathrm{ab}$ & $1.16 \pm 0.18 \mathrm{ab}$ & $1.21 \pm 0.07 \mathrm{a}$ & $0.91 \pm 0.37 \mathrm{ab}$ \\
\hline S-type & & $3.00 \pm 0.12 c$ & $4.78 \pm 0.46 b$ & $7.59 \pm 0.76 \mathrm{a}$ & $4.74 \pm 0.07 b$ & $4.37 \pm 0.16 b$ & $4.57 \pm 0.34 b$ \\
\hline$\%$ hydrolysis & & $5.16 \pm 1.59 b$ & $18.56 \pm 7.08 b$ & $5.44 \pm 4.97 b$ & $23.88 \pm 19.56 b$ & $10.45 \pm 0.01 b$ & $65.37 \pm 23.57 \mathrm{a}$ \\
\hline $\begin{array}{l}\text { Total flavonols - wet basis } \\
\text { (fruit, } \mathrm{mg} / \mathrm{kg} \text {; juice, } \mathrm{mg} / \mathrm{L} \text { ) }\end{array}$ & $82.62 \pm 7.25 \mathrm{~A}$ & $76.00 \pm 4.41 \mathrm{~A}$ & & & & & \\
\hline $\begin{array}{l}\text { Total flavonols - dry basis } \\
\quad(\mathrm{mg} / \mathrm{kg})\end{array}$ & & & $224.56 \pm 2.97 \mathrm{~A}$ & $110.19 \pm 8.13 \mathrm{~B}$ & $112.79 \pm 67.61 \mathrm{~B}$ & $82.49 \pm 1.27 \mathrm{C}$ & \\
\hline
\end{tabular}

Abbreviations: M, myricetin; Q, quercetin; L, larycitrin; I, isorhamnetin; S, syringetin; 3-glcU, 3-glucuronide, 3-glc, 3-glucoside. Different letters in the same line indicate significant differences by analysis of variance (ANOVA) and multiple comparison Tukey test or Student $t$ at $\mathrm{P}<0.05$. Lowercase letters are used for comparison between all samples and capital letters for comparison only between fruit and juice or between foams dehydrated by freeze-drying and by FMD at 60 , 70 and $80^{\circ} \mathrm{C}$. 
drying and measured anthocyanin concentrations of some samples (ranging from 5850 to $9930 \mathrm{mg} / \mathrm{kg}$ of powder) with values higher than those found in this study. However, the proportion of juice used in the formulations of the dry products were not comparable.

In order to evaluate the changes in anthocyanins as well as other phenolic compounds present in these products after juice dehydration, it is necessary to take into account not only the possible thermal or oxidative degradation of the compounds but also the concentration effect due to loss of water and dilution due to inclusion of additives to grape juice. The lyophilized sample showed approximately $100 \%$ retention of anthocyanins after comparison with the concentration of anthocyanins determined in the juice and taking into account the incorporation of the additives, with their respective moisture content, as well as the moisture content of the juice used and the final product. These results show that the freeze-drying process did not lead to degradation of the anthocyanins present in grape juice. In this way, this lyophilized foam was used as control of the FMD process. There was a statistically significant difference $(P<0.05)$ between anthocyanin concentrations of the dehydrated products using FMD at the three temperatures tested $\left(60,70\right.$ and $80^{\circ} \mathrm{C}$ ) and the control (lyophilized sample), observing content losses between 22 and $31 \%$. When comparing dehydrated products by FMD at different temperatures, it was seen that there was no statistically significant difference $(P<0.05)$ between the anthocyanin concentrations of the dehydrated products, which indicates that the increase in drying temperature was compensated by the reduction of the process time by up to approximately $57 \%$. This is different from the findings of other studies (Abbasi \& Azizpour, 2016; Tavares et al., 2017) where the concentrations of the anthocyanins were influenced by the temperature.

Barcia et al. (2014) dried BRS Violeta grape winemaking by-products using different methods and observed much higher losses (close to $94 \%$ ) of the anthocyanins content in the dried skin obtained by conventional drying at $50{ }^{\circ} \mathrm{C}$ compared with this product obtained by freeze-drying. Although there are losses during drying, these could be considered low in relation to the control, and the FMD of the BRS Violeta grape can be recommended for getting a dehydrated product rich in anthocyanins at any of the temperatures tested, with much lower energy spend.

In a paper from our research group, the FMD technique was used to dehydrate jambolan juice at 60,70 and $80{ }^{\circ} \mathrm{C}$ with drying times of 8.67 , 5.33 and $4.17 \mathrm{~h}$, respectively and lyophilized foam was used as process control. Compared with the present work with grape juice, the drying times of the jambolan juice were longer. However, the authors observed a degradation of anthocyanins of up to $32 \%$, a result quite close to that of this study, which is possible due the different profile of the anthocyanin of the jambolan and/or the higher concentration of maltodextrin $(20 \%)$ that was added to the jambolan juice. The effectiveness of maltodextrin as a protective agent for anthocyanins against degradation during extract or juice dehydration processes by freeze-drying and spray drying (Lao \& Giusti, 2017; Wilkowska et al., 2016; Yamashita et al., 2017) or during the storage of dehydrated products (Duangmal et al., 2008; Moser et al., 2017) has been well reported in the literature. Maltodextrin can form complex molecules with the flavylium cation of anthocyanins, preventing their transformation into less stable forms (Chandra, Nair, \& Iezzoni, 1993).

\subsection{Flavonols}

The flavonols profile of fresh grapes, juice and powdered products are presented in Table 2 and include 3-glucoside (3-glc) derivatives of myricetin (M), quercetin (Q), laricitrin (L), isorhamnetin (I) and syringetin (S), and 3-glucuronide derivatives (3-glcU) from M and Q. Derivatives of kaempferol $\mathrm{K}$ were not found. Rebello et al. (2013), in describing the flavonols present in BRS Violeta grape, also identified 3galactoside derivatives of $\mathrm{M}$ and $\mathrm{Q}$ that were not found in this study.

Table 2 shows that the flavonols derived from $M$ present in the juice
(M-3glc) and the dehydrated product at $80^{\circ} \mathrm{C}$ (M-3glc and $\left.\mathrm{M}-3 \mathrm{glcU}\right)$ presented significant reductions $(\mathrm{P}<0.05)$ of their molar proportions compared to their respective values in the grape itself. Conversely, there was a significant increase in the molar proportions of free myricetin (M-free) thus suggesting that hydrolysis of M glycosides partially occurred. In the products subjected to heat treatment (juices and dehydrated products obtained by FMD), other free aglycones (Q-free, Lfree, I-free and S-free) were also formed at lower molar proportions, mainly in the product dehydrated at $80^{\circ} \mathrm{C}$. Especially in the latter product, but also in some other cases, the standard deviations related to these molar proportions were very high, probably because the temperature is not the only factor affecting the degree of hydrolysis of the flavonol glycosides during the dehydration process, even in samples that are repetitions of the same dehydration experiment at the same tested temperature.

In the case of the grape and the lyophilized product, the occurrence of free $\mathrm{M}$ is considered to be produced by the use of acidic solutions during the preparation of the samples for HPLC analysis of the flavonols (Hermosín-Gutiérrez, Castillo-Muñoz, Gómez-Alonso, \& GarcíaRomero, 2011). M is the major flavonol aglycone of these samples and the most unstable in the case of degradative processes.

When recalculating the molar proportion data for the individually identified flavonols by aglycone type (Table 2), the M-type flavonols accounted for 66 to 77\%, followed by Q-type flavonols (16 to 24\%), thus, together they accounted for approximately 88 to $93 \%$ of the total flavonols present in the samples. This aglycone-type profile was similar to that reported by Moser et al. (2017) when producing a dehydrated product from the BRS Violeta grape juice using spray drying and by Barcia et al. (2014) when dried BRS Violeta grape winemaking byproducts (skins and less) by different methods (oven drying at $50^{\circ} \mathrm{C}$, spray-drying and freeze-drying). In addition, with the presentation of the results in this way, no such large standard deviations were obtained and, from the statistical analysis, it was concluded that the derived products presented a significant decrease in the molar ratios for the derivatives of $\mathrm{M}$ concomitantly with a significant increase, mainly, in the derivatives of $S$. This fact is justified because $\mathrm{M}$ has three $\mathrm{OH}$ groups in its $\mathrm{B}$ aromatic ring, while $\mathrm{S}$ has one $\mathrm{OH}$ group and two $\mathrm{OCH}_{3}$ groups in the B ring. The $\mathrm{OCH}_{3}$ group enhances aglycone stability, especially against oxidation and thermal degradation. Teleszko, Nowicka and Wojdylo (2016) also report that the formation of the free aglycones in the juices may be due to enzymatic hydrolysis of the flavonol glycosides during thermal processing. In the powdered products, especially at the highest temperature, the cleavage of the glycosidic bond was enhanced by thermohydrolysis, releasing the corresponding aglycones.

The concentration of flavonols present in the grape was approximately $83 \mathrm{mg} / \mathrm{kg}$ of fresh grapes as Q-3-glc equivalents (Table 2), which is lower than that reported by Rebello et al. (2013) $(156 \mathrm{mg} / \mathrm{kg})$. The average concentration found in the juice was approximately $76 \mathrm{mg} / \mathrm{L}$ of juice as Q-3-glc equivalents, that is $81 \%$ of the content found in the grape (after correction by the juice yield). The extraction of flavonols from grapes to juice was higher than that observed for anthocyanins in the same samples, likely because anthocyanins were more thermolabile and could have had greater losses during juice production.

The concentration of flavonols (as Q-3-glc/kg equivalent) present in the powdered products ranged from approximately 82 to $225 \mathrm{mg} / \mathrm{kg}$ of powder (dry basis). Moser et al. (2017), after dehydrating BRS Violeta grape juice with different proportions of maltodextrin and proteins (soy protein or whey protein) by spray drying, found concentrations of flavonols ranging from 267 to $316 \mathrm{mg} / \mathrm{kg}$ of product, some of the samples having values near to those determined in the present study.

There was a significant statistical difference $(P<0.05)$ at concentration of flavonol between the samples dried at different temperatures and between these samples and control (lyophilized sample). As occurred for anthocyanins, the retention of flavonols in the lyophilized sample relative to juice was approximately $100 \%$. When comparing the flavonol content of the powdered products at the three 
temperatures with the lyophilizated (control), reductions in flavonol concentrations ranging between 45 and $63 \%$, approximately, were seen, with the highest loss observed at $80^{\circ} \mathrm{C}$. There is no knowledge of other studies that performed FMD in grape juice and determined the concentration of flavonols. For comparison purposes, losses of $66 \%$ of flavonols were reported in a winemaking by-product (grape skins) of the BRS Violeta grape that was dehydrated by conventional drying at $50{ }^{\circ} \mathrm{C}$ and compared to the product obtained by freeze-drying (Barcia et al., 2014). These results demonstrate that the flavonols present in samples from BRS Violeta grapes are susceptible to high degradations when exposed to temperatures equal to or higher than $50^{\circ} \mathrm{C}$.

Tavares et al. (2017), using similar conditions for FMD of the jambolan juice did not found differences between the samples dried in the driers and the control sample (lyophilized). This distinct behavior could be inherent to the different flavonol profiles, along with other phenolic compounds, of the matrices used, as well as different drying times and concentration of additives.

\subsection{Hydroxycinnamic acid derivatives (HCAD)}

In the grape, juice and powdered products, a total of eleven HCAD were found (Table 3), namely, trans-caftaric acid, trans- and cis-coutaric acids, trans- and cis-fertaric acids, three isomeric combinations of caffeic acid with glucose ( $p$-caffeoyl-glucose-1, $p$-caffeoyl-glucose-2 and $p$ caffeoyl-glucose-3) and three isomeric combinations of $p$-coumaric acid with glucose ( $p$-coumaroyl-glucose-1, $p$-coumaroyl-glucose-2, $p$-coumaroyl-glucose-3). These same HCAD were found by Rebello et al. (2013) when studying the different parts of the BRS Violeta grape and are also in agreement with the results reported by Moser et al. (2017) in BRS Violeta grape juice powder obtained by spray drying, except that in those works did not find the cis-coutaric acid and the isomers of fertaric acid, and that was also found free caffeic acid. The two most prevalent individual HCAD in the samples analyzed were trans-fertaric acid derivatives (16 to 34\%) and trans-caftaric acid (9-25\%).

In all the samples, the GRP (Grape Reaction Product or 2-S-glutathionyl-trans-caftaric acid) was detected in high molar proportions (21-29\%). Barcia et al. (2014) also found this compound in BRS Lorena grapes, which presented a large variability between different vintage years: 7 and $29 \%$ respectively for the years 2011 and 2012. In the whole grapes, the presence of the GRP is an artifact due to the manipulation of the samples during the homogenization step to obtain the phenolic extracts. The homogenization of the grape allows contact between the oxidizable substrates (HCAD), the endogenous enzymes (polyphenoloxidase and peroxidase) and the necessary reactive oxygen that triggers the oxidation process of the HCAD, which consequently results in the formation of $o$-quinones. Subsequently, these $o$-quinones, which are very reactive, can react with multiple compounds such as glutathione, which is detected in the grapes and their corresponding dried products, forming GRP.

The high formation of degradation products in the grape may explain the low concentration of HCAD found $(39.57 \mathrm{mg} / \mathrm{kg}$ of fresh grape as caffeic acid equivalent) (Table 3), when compared to the value reported by Rebello et al. (2013) for the same grape cultivar (133.90 mg/ $\mathrm{kg}$ ). However, it is important to note that the method of analysis for HCAD determination has limitations, since only native grape derivatives and one of their initial reaction products, GRP, can be identified and quantified, apart from some of the hydrolysis products (hydroxycinnamic acids). In addition, the intermediate oxidation products, such as $o$-quinones, formed during the degradation process are not quantifiable by the method used and may continue to react until they form polymerized compounds that are not extracted or that precipitate in the extract.

In the juice, unlike the anthocyanins and flavonols, the concentration of HCAD ( $77 \mathrm{mg} / \mathrm{L}$ juice as caftaric acid equivalent) was significantly higher than that of the grape, resulting in an increase of approximately $73 \%$ (after correcting for the juice yield). Genova, Tosetti, and Tonutti (2016), after pasteurizing $\left(30 \mathrm{~min}\right.$ at $\left.78^{\circ} \mathrm{C}\right)$ coldextracted Sangiovese (Vitis vinifera) grape juice reported an increase of between 3.76 and $9.90 \%$ in the HCAD content, depending on the date of harvest and the pre-treatment applied to the grape. In the present work, the grape berry was placed intact in the extraction pan and extraction of the juice was carried out using saturated steam. In these conditions, the HCAD present in the grapes may have been better protected from enzymatic oxidative processes, likely because the temperature inactivated

Table 3

Hydroxycinnamic acid derivatives (HCAD) in BRS Violeta grape, juice and powdered products (foams dehydrated by freeze-drying and by FMD at 60,70 and $80{ }^{\circ} \mathrm{C}$ ) by HPLC-DAD-ESI-MS/MS (negative ionization mode). MS and MS/MS spectra data, molar \% (percentage of each individual HCAD regarding the total content), and total concentrations (as equivalents of caftaric acid). Given as mean values \pm standard deviation $(\mathrm{n}=3)$.

HCAD

\begin{tabular}{|c|c|c|c|c|c|c|c|}
\hline & $\begin{array}{l}\text { Molecular ion; product ions } \\
(\mathrm{m} / z)\end{array}$ & Grape & Juice & Freeze-drying & \multicolumn{3}{|l|}{ Foam mat drying } \\
\hline GRP & & $29.32 \pm 1.45 \mathrm{a}$ & $26.86 \pm 4.65 \mathrm{a}$ & $21.70 \pm 1.22 \mathrm{a}$ & $23.99 \pm 1.86 \mathrm{a}$ & $22.09 \pm 1.09 \mathrm{a}$ & $20.84 \pm 5.57 \mathrm{a}$ \\
\hline caffeoyl-glucose 1 & $341 ; 179,161,135$ & $0.75 \pm 0.23 \mathrm{~b}$ & $1.20 \pm 0.71 \mathrm{ab}$ & $1.56 \pm 0.35 \mathrm{ab}$ & $1.34 \pm 1.01 \mathrm{ab}$ & $2.68 \pm 0.03 \mathrm{a}$ & $0.81 \pm 0.15 \mathrm{ab}$ \\
\hline caffeoyl-glucose 2 & $341 ; 179,161,135$ & $1.15 \pm 0.09 c$ & $2.75 \pm 0.47 \mathrm{ab}$ & $1.71 \pm 1.36 \mathrm{bc}$ & $3.93 \pm 0.42 \mathrm{a}$ & $3.44 \pm 0.03 \mathrm{ab}$ & $3.41 \pm 0.26 \mathrm{ab}$ \\
\hline trans-coutaric acid & $325 ; 193,149,119$ & $3.31 \pm 0.19 \mathrm{ab}$ & $1.94 \pm 0.40 \mathrm{bc}$ & $1.01 \pm 1.13 c$ & $1.90 \pm 0.12 \mathrm{bc}$ & $1.84 \pm 0.28 \mathrm{bc}$ & $4.67 \pm 1.61 \mathrm{a}$ \\
\hline cis-coutaric acid & $325 ; 193,149,119$ & $1.68 \pm 0.37 \mathrm{a}$ & $0.00 \pm 0.00 c$ & $0.00 \pm 0.00 c$ & $0.79 \pm 0.09 b$ & $0.66 \pm 0.21 b$ & $0.00 \pm 0.00 c$ \\
\hline trans-fertaric acid & $325 ; 193,149$ & $15.98 \pm 1.64 \mathrm{~b}$ & $30.95 \pm 2.82 \mathrm{a}$ & $33.14 \pm 1.32 \mathrm{a}$ & $33.63 \pm 0.45 \mathrm{a}$ & $34.38 \pm 0.64 \mathrm{a}$ & $23.03 \pm 7.32 b$ \\
\hline cis- fertaric acid & $325 ; 193,149$ & $3.64 \pm 0.46 \mathrm{a}$ & $4.29 \pm 0.70 \mathrm{a}$ & $5.27 \pm 0.84 \mathrm{a}$ & $4.33 \pm 0.56 \mathrm{a}$ & $4.04 \pm 0.47 a$ & $3.99 \pm 0.50 \mathrm{a}$ \\
\hline$p$ - coumaroyl-glucose 2 & $325 ; 163,145$ & $8.99 \pm 0.63 \mathrm{ab}$ & $10.17 \pm 2.06 \mathrm{ab}$ & $12.96 \pm 2.60 \mathrm{a}$ & $11.21 \pm 0.08 \mathrm{ab}$ & $12.05 \pm 0.05 \mathrm{ab}$ & $6.98 \pm 3.48 \mathrm{~b}$ \\
\hline$p$ - coumaroyl-glucose 3 & $325 ; 163,145$ & $3.63 \pm 0.46 \mathrm{a}$ & $4.29 \pm 0.70 \mathrm{a}$ & $5.27 \pm 0.84 \mathrm{a}$ & $4.33 \pm 0.56 \mathrm{a}$ & $4.04 \pm 0.75 \mathrm{a}$ & $3.99 \pm 0.05 \mathrm{a}$ \\
\hline $\begin{array}{l}\text { Total HCAD - wet basis } \\
\text { (fruit, mg/kg; juice, mg/L) }\end{array}$ & $39.57 \pm 2.86 \mathrm{~B}$ & $77.49 \pm 3,53 \mathrm{~A}$ & & & & & \\
\hline $\begin{array}{l}\text { Total HCAD - dry basis } \\
(\mathrm{mg} / \mathrm{kg})\end{array}$ & & & $263.10 \pm 9.65 \mathrm{~A}$ & $145.94 \pm 6.25 \mathrm{~B}$ & $173.47 \pm 5.39 \mathrm{~B}$ & $69.83 \pm 10.45 C$ & \\
\hline
\end{tabular}

Abbreviations: GRP, 2-S-glutathionyl-trans-caftaric acid. Different letters in the same line indicate significant differences by analysis of variance (ANOVA) and Tukey multiple comparison test or Student $t$ at $\mathrm{P}<0.05$. Lowercase letters are used for comparison between all samples and capital letters for comparison only between fruit and juice or between foams dehydrated by freeze-drying and by FMD at 60,70 and $80^{\circ} \mathrm{C}$.

Molar \%

Powdered products

Freeze-drying mat drying

\section{GRP}

trans-caftaric aci $341 ; 179,161,135$ $341 ; 179,161,135$ $325 ; 193,149,119$ $325 ; 163,145$ $39.57 \pm 2.86 \mathrm{~B}$ $3.31 \pm 0.19 \mathrm{ab} \quad 1.94 \pm 0.40 \mathrm{bc}$ $30.95 \pm 2.82 \mathrm{a}$ $8.99 \pm 0.63 \mathrm{ab} \quad 10.17 \pm 2.06 \mathrm{a}$ $21.70 \pm 1.22 \mathrm{a}$ $1.71 \pm 1.36 \mathrm{bc}$ $11.21 \pm 0.08 \mathrm{ab}$ caffeoyl-glucose 3 p- coumaroyl-glucose 3 HCAD - dry basis $(\mathrm{mg} / \mathrm{kg})$ 
the enzymes involved as well as the water vapor replacing, in part, the air inside the extracting pan, which, in turn, resulted in a product with higher concentration of these compounds.

The amount of HCAD present in the powdered products (as $\mathrm{mg}$ equivalent of caftaric acid) ranged from approximately $70-263 \mathrm{mg} / \mathrm{kg}$ powder (dry basis). Moser et al. (2017), after dehydrating BRS Violeta grape juice by spray drying, reported concentrations of HCAD in the resulting powders $(242.6-327.5 \mathrm{mg} / \mathrm{kg}$ of powder close to those obtained in the present study. Barcia et al. (2014) studying the dried skin by-products of BRS Violeta grape winemaking, observed a loss in the HCAD content similar to this study (68\%) when comparing the skin dried by conventional drying at $50{ }^{\circ} \mathrm{C}$ to the same product obtained by freeze-drying.

As for anthocyanins and flavonols, the retention of HCAD in the lyophilized sample relative to juice was approximately $100 \%$, which shows that the freeze-drying process also did not lead to the degradation of the HCAD. Therefore, when comparing the HCAD concentrations of the powdered products with heated air at different temperatures and the lyophilized product (control) it was verified that there is statistically significant difference $(\mathrm{P}<0.05)$, with reductions ranging from 35 to $73 \%$, and higher losses at $80{ }^{\circ} \mathrm{C}$. Unlike the marked effect of thermal degradation that occurs in anthocyanins, for HCAD the most important factor was oxidative degradation, when comparing powdered products with hot air flow and lyophilized products (in the absence of air). In addition, a significant difference $(P<0.05)$ was observed between the HCAD concentrations of the product dehydrated at $80{ }^{\circ} \mathrm{C}$ and those determined in products dehydrated at 60 and $70{ }^{\circ} \mathrm{C}$. Because the derivatives of the hydroxycinnamic acids are chemically more susceptible to oxidative degradation, the results in this case suggested that, by raising the temperature above $70^{\circ} \mathrm{C}$, an accelerating effect of oxidative degradation occurred, since the increase in the temperature increases the rate of reaction, with consequent reduction in the total concentration of these compounds. Dehydrated products at $80^{\circ} \mathrm{C}$ showed a $73 \%$ reduction when compared to the control (lyophilized product).

\subsection{Changes in TPC and $A A$}

The content of total phenolic compounds (TPC) and the values of antioxidant activity (AA) for the BRS Violeta grape, juice and powdered products are presented in Table 4. The TPC of the BRS Violeta grape was $3.51 \pm 0.39 \mathrm{mg} / \mathrm{g}$ of grape as GAE and and AA values were $32.79 \pm 3.31 \mu \mathrm{mol} / \mathrm{g}$ grape as Trolox equivalent (or $76.53 \pm 7.92 \mu \mathrm{mol} / \mathrm{g}$ as $\mathrm{Fe}_{2} \mathrm{SO}_{4}$ equivalent) by the FRAP method and $17.27 \pm 0.08 \mu \mathrm{mol} / \mathrm{g}$ of grape as Trolox equivalent by the DPPH method, respectively. For the Bordô grape (Vitis labrusca), Lago-Vanzela et al. (2011) reported values for TPC and AA by the DPPH method of $1.13 \mathrm{mg} / \mathrm{g}$ and $37.60 \mu \mathrm{mol} / \mathrm{g}$, respectively.

Regarding the juice, a TPC concentration of $4.01 \pm 0.27 \mathrm{mg} / \mathrm{mL}$ juice as GAE as well as AA of $42.19 \pm 4.12 \mu \mathrm{mol} / \mathrm{mL}$ (FRAP method) was determined as Trolox equivalents (or $99.11 \pm 9.85 \mu \mathrm{mol} / \mathrm{mL}$ as $\mathrm{Fe}_{2} \mathrm{SO}_{4}$ equivalent) and $32.95 \pm 3.09 \mu \mathrm{mol} / \mathrm{mL}$ as Trolox equivalent (DPPH method), respectively. Lima et al. (2014), after destemming the BRS Violeta grape, crushing, treating enzymatically with pectinase ( $3 \mathrm{~mL} / 100 \mathrm{~kg}$ of grape) and macerating at $60^{\circ} \mathrm{C}$ for $1 \mathrm{~h}$, obtained juice containing a lower TPC concentration ( $2.72 \mathrm{mg} \mathrm{GAE} / \mathrm{mL})$, although this value was higher than those reported for other cultivars such as Isabel, BRS Cora and BRS Magna grapes $(0.78,1.9$ and $2.10 \mathrm{mg} \mathrm{GAE} / \mathrm{mL}$, respectively). The latter study also reported an AA value for the BRS Violeta grape by the DPPH method of $51.6 \mathrm{mM}$ Trolox/L, being higher than that found in this study and even higher than the other mentioned grapes (11.5, 44.2 and $49.2 \mathrm{mM}$ Trolox/L, respectively for Isabel, BRS Cora and BRS Magna grapes).

When comparing the TPC concentration of the grape and the juice (taking into account the juice yield), only a slight increase of approximately $1.2 \%$ was observed. It is worth noting that many compounds present naturally in fruits or that are incorporated during extraction may interfere in the quantification of TPC by the Folin-Ciocalteu method (Prior, Wu, \& Schaich, 2005).

Regarding the AA determined by the DPPH method, there was an increase of $69 \%$ from the grape to the juice (taking into account juice yield). Literature data reported an increase in AA by processing using higher temperatures. Nicoli, Anese, and Parpinel (1999) reported an example of the different simultaneous reactions that may occur in the plant matrix subjected to short or long term heat treatment. For short heat treatments, a reduction in overall AA due to the loss of naturally occurring antioxidants and/or the formation of pro-oxidants due to Maillard reaction can be detected. A prolonged warm-up time, on the other hand, generates a loss of these compounds which can be minimized by a recovery or even an improvement in AA due to the formation of advanced Maillard reaction products. Castilhos et al. (2016) also report that there was influence of temperature on the antioxidant activity of BRS Violeta grape wines when alternative winemaking procedures of grape pre-drying.

In the present study, the powdered products still showed a high concentration of TPC and relevant AA, even undergoing oxidative and thermal degradation processes. Moser et al. (2017) when producing powders also from BRS Violeta grape juice by spray drying, found higher AA values $(79.4-110.6 \mu \mathrm{mol} / \mathrm{g}$ as Trolox equivalent, by the DPPH method) than those found in this work.

The analysis of the individual phenolic compounds indicated different responses of the compounds to the FMD processes at different temperatures, and when analyzing TPC and AA in the samples, a significant difference $(P<0.05)$ was observed between the values for the lyophilized product and those air-dried at 60,70 and $80^{\circ} \mathrm{C}$. The TPC and AA by the DPPH and FRAP method had a reduction compared to the lyophilized sample (control) of 8 to $16 \%, 9$ to $21 \%$ and 7 to $17 \%$, respectively, being values of AA values found were higher when AA was determined by the frap method than by the DPPH method. The AA of

Table 4

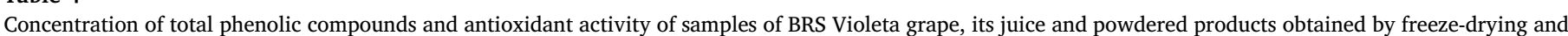
by FMD at 60,70 and $80^{\circ} \mathrm{C}$.

\begin{tabular}{|c|c|c|c|c|}
\hline \multirow[t]{2}{*}{ Samples $^{1}$} & \multirow[t]{2}{*}{ TPC (mg of GAE)/g or $\mathrm{mL}$} & \multicolumn{3}{|l|}{ Antioxidant Activity } \\
\hline & & FRAP $(\mu \mathrm{mol}$ of FS/g or $\mathrm{mL})$ & FRAP ( $\mu$ mol of Trolox/g or $\mathrm{mL})$ & DPPH $(\mu \mathrm{mol}$ of Trolox/g or $\mathrm{mL})$ \\
\hline Fruit & $3.51 \pm 0.39 \mathrm{~A}$ & $76.53 \pm 7.92 \mathrm{~B}$ & $32.79 \pm 3.31 \mathrm{~B}$ & $17.27 \pm 0.08 \mathrm{~B}$ \\
\hline Juice & $4.01 \pm 0.27 \mathrm{~A}$ & $99.11 \pm 9.85 \mathrm{~A}$ & $42.19 \pm 4.12 \mathrm{~A}$ & $32.95 \pm 3.09 \mathrm{~A}$ \\
\hline Dehydrated product at freeze-drying & $9.73 \pm 0.01 \mathrm{a}$ & $207.42 \pm 3.28 \mathrm{a}$ & $88.98 \pm 1.36 \mathrm{a}$ & $39.75 \pm 0.15 \mathrm{a}$ \\
\hline Dehydrated product at FMD $\left(60^{\circ} \mathrm{c}\right)$ & $8.15 \pm 0.64 \mathrm{ab}$ & $173.16 \pm 2.32 \mathrm{c}$ & $74.52 \pm 0.97 c$ & $31.47 \pm 0.79 c$ \\
\hline Dehydrated product at FMD $\left(70^{\circ} \mathrm{c}\right)$ & $8.34 \pm 0.27 b$ & $192.67 \pm 3.55 \mathrm{ab}$ & $82.76 \pm 1.15 \mathrm{ab}$ & $33.24 \pm 0.83 c$ \\
\hline Dehydrated product at FMD $\left(80^{\circ} \mathrm{c}\right)$ & $8.98 \pm 0.61 b$ & $178.88 \pm 6.42 \mathrm{bc}$ & $76.98 \pm 1.36 \mathrm{bc}$ & $36.10 \pm 1.10 \mathrm{~b}$ \\
\hline
\end{tabular}

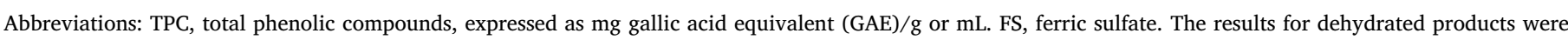

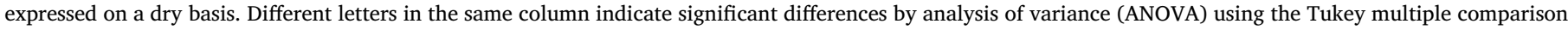

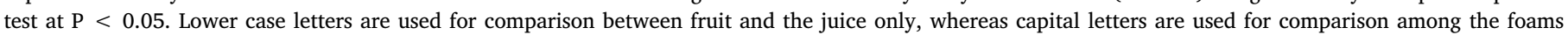
dehydrated by freeze-drying and by FMD at 60,70 and $80{ }^{\circ} \mathrm{C}$. 
the dehydrated product at $70{ }^{\circ} \mathrm{C}$, determined by the FRAP method, did not differ from the AA determined in the lyophilized product (control). Tavares et al. (2017), using similar conditions for FMD of the jambolan juice did not found differences between the samples dried in the driers and the control sample (lyophilized), also the values of AA values found were higher when AA was determined by the frap method than by the DPPH method. In a other study, by Sogi, Siddiq, and Dolan (2015), dried Tommy mango cubes $(10 \mathrm{~mm})$ were obtained by testing several drying methods (freeze-drying, conventional drying and vacuum at $60^{\circ} \mathrm{C}$ and infrared). After analyzing AA by several methods, no statistical difference was found between samples dried by freeze-drying and conventional drying by the DPPH method, whereas statistical differences were found regarding the ABTS, FRAP and ORAC methods.

Depending on the method used, there is a difference between the values of AA due to the different mechanisms of determination of AA. Being of paramount importance the analysis of AA by more than one method, because the complexity of the composition of the materials analyzed in the present study can lead to an underestimation of the AA.

\section{Conclusions}

Analyses of the qualitative and quantitative changes on the phenolic compounds of the evaluated in the grape and juice showed that flavonols and, especially HCADs extraction, by means saturated steam, were favored in comparison to anthocyanins extraction. With regard to deydrated products, those obtained by the FMD method at different temperatures $\left(60,70\right.$ e $\left.80^{\circ} \mathrm{C}\right)$ showed PCs concentrations lower than the freeze-dried product, however, at $70{ }^{\circ} \mathrm{C}$ these substances were more preserved. Comparing effects of drying temperatures only on the products obtained by FMD, it is observed that anthocyanins were not statistically affected by the drying temperature changes, while, flavanols and HCAD were affected by temperature increase. It is worth highlighting that at $80^{\circ}$, an important reduction in the drying time was obtained. This work confirms the feasibility of using the FMD technique to obtain dehydrated products of the BRS Violeta grape with potential for use as an ingredient and/or coloring in the preparation of healthier food products.

\section{Acknowledgements}

We would like, especially, to thank Prof. Dr. Isidro HermosínGutiérrez (in memoriam), who made a huge contribution to this research and paper and who, unfortunately, passed away (April 23 ${ }^{\text {th }}, 2018$ ) before its being published. We also thank EMBRAPA Grape and Wine (Jales, Brazil) for BRS Violeta grape supply.

\section{Funding}

This work was supported by the Coordination of Improvement of Higher Education Personnel (CAPES) (Finance Code 001 and grant number PDSE 99999.012757/2013-06); São Paulo Research Foundation (FAPESP) (grant numbers 2013/19057-2, 2014/11514-8 and 2017/16482-5). The sponsors had no role in study design; in the collection, analysis and interpretation of data; in the writing of the report; and in the decision to submit the article for publication.

\section{Declaration of Competing Interest}

The authors declare no conflicts of interest.

\section{Authors' contributions}

All authors approved the final article.

\section{References}

Abbasi, E., \& Azizpour, M. (2016). Evaluation of physicochemical properties of foam mat dried sour cherry powder. LWT - Food Science and Technology, 68, 105-110. https:// doi.org/10.1016/j.lwt.2015.12.004.

AOAC, Association of Official Analytical Chemists. (2005). Official methods of analysis of the association analytical chemists (18th ed.) Gaithersburg.

Barcia, M. T., Pertuzatti, P. B., Gómez-Alonso, S., Godoy, H. T., \& Hermosín-Gutiérrez, I. (2014). Phenolic composition of grape and winemaking by-products of Brazilian hybrid cultivars BRS Violeta and BRS Lorena. Food Chemistry, 159, 95-105. https:// doi.org/10.1016/j.foodchem.2014.02.163.

Bastos, D. da S., Soares, D. M. B. G., Araújo, K. G. de L., \& Verruma-Bernardi, M. R. (2005). Desidratação da polpa de manga " Tommy Atkins " Utilizando a técnica de fam mat drying - avaliações químicas, físico-químicas e sensoriais. Brazilian Journal of Food Technology, 8(4), 283-290.

Benzie, I. F., \& Strain, J. J. (1996). The ferric reducing ability of plasma (FRAP) as a measure of "antioxidant power": The FRAP assay. Analytical Biochemistry, 239(1), 70-76. https://doi.org/10.1006/abio.1996.0292.

Brand-Williams, W., Cuvelier, M. E., \& Berset, C. (1995). Use of a free radical method to evaluate antioxidant activity. LWT - Food Science and Technology, 28(1), 25-30. https://doi.org/10.1016/S0023-6438(95)80008-5.

Breda, C. A., Justi, P. N., \& Sanjinez-Argandoña, E. J. (2013). Efeito da desidratação foam mat na retenção da vitamina C. Alimentos e Nutrição, 242, 189-193.

Bresolin, B., Gularte, M. A., \& Manfroi, V. (2013). Água exógena em suco de uva obtido pelo método de arraste a vapor. Revista Brasileira de Tecnologia Agroindustrial, 7(1), 922-933. https://doi.org/10.3895/rbta.v7i1.1040.

Castilhos, M. B. M., Tavares, I. M. de C., Gómez-Alonso, S., García-Romero, E., Del Bianchi, V. L., \& Hermosín-Gutiérrez, I. (2016). Phenolic composition of BRS Violeta red wines produced from alternative winemaking techniques: relationship with antioxidant capacity and sensory descriptors Phenolic composition of BRS Violeta red wines produced from alternative winemaking techniques. European Food Research and Technology, 242(11), 1913-1923. https://doi.org/10.1007/s00217-016-2691-3.

Castillo-Muñoz, N., Gómez-Alonso, S., García-Romero, E., Gómez, M. V., Velders, A. H., \& Hermosín-Gutiérrez, I. (2009). Flavonol 3-O-glycosides series of Cv. Petit Verdot red wine grapes. Journal of Agricultural and Food Chemistry, 57(1), 209-219 Retrieved from http://pubs.acs.org/doi/abs/10.1021/jf802863g.

Chandra, A., Nair, M. G., \& Iezzoni, A. F. (1993). Isolation and Stabilization of Anthocyanins from Tart Cherries (Prunus cerasus L.). Journal of Agricultural and Food Chemistry, 9, 1062-1065.

Cortez, R., Luna-Vital, D. A., Margulis, D., \& De Mejia, E. G. (2017). Natural pigments: Stabilization methods of anthocyanins for food applications. Comprehensive Reviews in Food Science and Food Safety, 16(1), 180-198. https://doi.org/10.1111/1541-4337. 12244.

Duangmal, K., Saicheua, B., \& Sueeprasan, S. (2008). Colour evaluation of freeze-dried roselle extract as a natural food colorant in a model system of a drink. LWT - Food Science and Technology, 41(8), 1437-1445. https://doi.org/10.1016/j.lwt.2007.08. 014.

Dutra, M. da C. P., Lima, M. dos S., Barros, A. P. A., Mascarenhas, R. de J., \& Lafisca, A. (2014). Influência da variedade de uvas nas características analíticas e aceitação sensorial do suco artesanal. Revista Brasileira de Produtos Agroindustriais, 16(3), 265-272.

Ekpong, A., Phomkong, W., \& Onsaard, E. (2016). The effects of maltodextrin as a drying aid and drying temperature on production of tamarind powder and consumer acceptance of the powder. International Food Research Journal, 23(1), 300-308.

Genova, G., Tosetti, R., \& Tonutti, P. (2016). Berry ripening, pre-processing and thermal treatments affect the phenolic composition and antioxidant capacity of grape (Vitis vinifera L.) juice. Journal of the Science of Food and Agriculture, 96(2), 664-671. https://doi.org/10.1002/jsfa.7138.

Granato, D., de Magalhães Carrapeiro, M., Fogliano, V., \& van Ruth, S. M. (2016). Effects of geographical origin, varietal and farming system on the chemical composition and functional properties of purple grape juices: A review. Trends in Food Science and Technology, 52, 31-48. https://doi.org/10.1016/j.tifs.2016.03.013.

Guimarães, M. K. A., Figueirêdo, M. R. F., \& Queiroz, A. J. M. (2017). Foam-mat drying kinetics of keitt mango pulp. Revista Caatinga, 30(1), 172-180.

Hermosín-Gutiérrez, I., Castillo-Muñoz, N., Gómez-Alonso, S., \& García-Romero, E. (2011). Flavonol profiles for grape and wine authentication. In S. E. Ebeler, G. R. Takeoka, \& P. Winterhalter (Eds.). Progress in Authentication of Food and Wine (pp. 113-129). Washington, DC: ACS Symposium Series.

Lago-Vanzela, E. S., Da-Silva, R., Gomes, E., García-Romero, E., \& Hermosín-Gutiérrez, I. (2011). Phenolic composition of the edible parts (flesh and skin) of Bordô grape (Vitis labrusca) using HPLC-DAD-ESI-MS/MS. Journal of Agricultural and Food Chemistry, 59(24), 13136-13146. https://doi.org/10.1021/jf203679n.

Lago-Vanzela, E. S., Procópio, D. P., Fontes, E. A. F., Ramos, A. M., Stringheta, P. C., DaSilva, R., ... Hermosín-Gutiérrez, I. (2014). Aging of red wines made from hybrid grape cv. BRS Violeta: Effects of accelerated aging conditions on phenolic composition, color and antioxidant activity. Food Research International, 56, 182-189. https:// doi.org/10.1016/j.foodres.2013.12.030.

Lao, F., \& Giusti, M. M. (2017). The effect of pigment matrix, temperature and amount of carrier on the yield and final color properties of spray dried purple corn (Zea mays L.) cob anthocyanin powders. Food Chemistry, 227, 376-382. https://doi.org/10.1016/j. foodchem.2017.01.091.

Lima, M. D. S., Silani, I. D. S. V., Toaldo, I. M., Corrêa, L. C., Biasoto, A. C. T., Pereira, G. E., ... Ninow, J. L. (2014). Phenolic compounds, organic acids and antioxidant activity of grape juices produced from new Brazilian varieties planted in the Northeast Region of Brazil. Food Chemistry, 161, 94-103. https://doi.org/10.1016/j.foodchem. 
2014.03.109.

Moser, P., Telis, V. R. N., Neves, N. A., García-Romero, E., Gómez-Alonso, S., \& HermosínGutiérrez, I. (2017). Storage stability of phenolic compounds in powdered BRS Violeta grape juice microencapsulated with protein and maltodextrin blends. Food Chemistry, 214, 308-318. https://doi.org/10.1016/j.foodchem.2016.07.081.

Nicoli, M., Anese, M., \& Parpinel, M. (1999). Influence of processing on the antioxidant properties of fruit and vegetables. Trends in Food Science \& Technology, 10(3), 94-100. https://doi.org/10.1016/S0924-2244(99)00023-0.

Ough, C. S., \& Amerine, M. A. (1988). Methods for analysis of musts and wines (2nd ed.). New York: John Wiley \& Sons.

Prior, R. L., Wu, X., \& Schaich, K. (2005). Standardized methods for the determination of antioxidant capacity and phenolics in foods and dietary supplements. Journal of Agricultural and Food Chemistry, 53, 4290-4302.

Rebello, L. P. G., Lago-Vanzela, E. S., Barcia, M. T., Ramos, A. M., Stringheta, P. C., DaSilva, R., ... Hermosín-Gutiérrez, I. (2013). Phenolic composition of the berry parts of hybrid grape cultivar BRS Violeta (BRS Rubea $\times$ IAC 1398-21) using HPLC-DAD-ESIMS/MS. Food Research International, 54(1), 354-366. https://doi.org/10.1016/j. foodres.2013.07.024.

Rizzon, L. A., Manfroi, V., \& Meneguzzo, J. (1998). Elaboração de suco de uva na propriedade vitícola (21st ed.). Banto Gonçalves: Embrapa Uva e Vinho.

Saavedra-Leos, M. Z., Alvarez-Salas, C., Esneider-Alcalá, M. A., Toxqui-Terán, A., PérezGarcía, S. A., \& Ruiz-Cabrera, M. A. (2012). Towards an improved calorimetric methodology for glass transition temperature determination in amorphous sugars. CyTA - Journal of Food, 10(4), 258-267. https://doi.org/10.1080/19476337.2011. 639960.

Sangamithra, A., Venkatachalam, S., John, S. G., \& Kuppuswamy, K. (2015). Foam mat drying of food materials: A Review. Journal of Food Processing and Preservation, 39(6), 3165-3174. https://doi.org/10.1111/jfpp.12421.

Seerangurayar, T., Manickavasagan, A., Al-Ismaili, A. M., \& Al-Mulla, Y. A. (2017). Effect of carrier agents on flowability and microstructural properties of foam-mat freeze dried date powder. Journal of Food Engineering, 215, 33-43. https://doi.org/10.1016/ j.jfoodeng.2017.07.016.

Sogi, D. S., Siddiq, M., \& Dolan, K. D. (2015). Total phenolics, carotenoids and antioxidant properties of Tommy Atkin mango cubes as affected by drying techniques. LWT - Food Science and Technology, 62(1), 564-568. https://doi.org/10.1016/j.lwt.2014.04.015.

Tavares, I. M. de C., Nogueira, T. Y. K., Mauro, M. A., Gómez-Alonso, S., Da-Silva, R., Hermosín-Gutiérrez, I., \& Lago-Vanzela, E. S. (2017). Dehydration of jambolan [Syzygium cumini (L.)] juice during foam mat drying: Quantitative and qualitative changes of the phenolic compounds. Food Research International, 102, 32-42. https:// doi.org/10.1016/j.foodres.2017.09.068.

Tavares, I. M. C., Lago-Vanzela, E. S., Rebello, L. P. G., Ramos, A. M., Gómez-Alonso, S., García-Romero, E., ... Hermosín-Gutiérrez, I. (2016). Comprehensive study of the phenolic composition of the edible parts of jambolan fruit (Syzygium cumini (L.) Skeels). Food Research International, 82, 771-779. https://doi.org/10.1016/j.foodres. 2016.01.014.

Teleszko, M., Nowicka, P. \& Wojdyło, A. (2016). Effect of cultivar and storage temperature on identification and stability of polyphenols in strawberry cloudy juices. Journal of Food Composition and Analysis, 54, 10-19. https://doi.org/10.1016/j.jfca. 2016.09.009.

Wilkowska, A., Ambroziak, W., Czyzowska, A., \& Adamiec, J. (2016). Effect of microencapsulation by spray-drying and freeze-drying technique on the antioxidant properties of blueberry (Vaccinium myrtillus) juice polyphenolic compounds. Polish Journal of Food and Nutrition Sciences, 66(1), 11-16. https://doi.org/10.1515/pjfns2015-0015.

World Geodetic System. 1984. < https://gis.icao.int/eganp/webpdf/REF08-Doc9674. pdfl > . Accessed March 2018.

Yamashita, C., Mi, M., Chung, S., Roberta, C., Mayer, M., Cristina, I., \& Moraes, F. (2017) Microencapsulation of an anthocyanin-rich blackberry (Rubus spp.) by-product extract by freeze-drying. LWT - Food Science and Technology, 84, 256-262. https://doi. org/10.1016/j.lwt.2017.05.063. 